\title{
Analysis on the Promotion of "Double-tutor System" to Academic Atmosphere Construction in Universities
}

\author{
Fan-Gang Meng ${ }^{1,}$, Kai Wang ${ }^{1, b}$ * \\ ${ }^{1}$ Beihua University, Jilin, China \\ a z13140oy@163.com , b178971787@qq.com \\ ${ }^{*}$ Corresponding author
}

Keywords: Double-tutor System; academic atmosphere; construction in universities

\begin{abstract}
Talent cultivation in universities are developing into a direction of high quality, high competency, diversification mode and compound type. Setting a tutorial system will exert a profound influence on cultivation of students' good ideological and moral quality, academic research attitude and promotion of learning motivation. Especially the academic atmosphere construction in universities is a systematic project which has a relevance to every aspect of higher education, thus a cooperation of multiple departments is needed. Now academic atmosphere in universities has many problems, with provincial general colleges and universities as examples, this paper makes a survey on present situation and demand of academic atmosphere by means of questionnaire, proposes that academic atmosphere construction is an integrated business combining ideological together with political work and academic features and it needs counselors and professional mentors form a joint force to play their respective advantages to the greatest extent and work together for academic atmosphere construction. Therefore, this paper emphasizes on the discussion of the relations between college double-tutor system and good academic atmosphere construction, teaching quality improvement and other aspects.
\end{abstract}

\section{Introduction}

A good academic atmosphere and school spirit is very important for building a university image, which has both an outer and inner part. The campus planning, architectural style and so on are the outer part, while the spiritual outlook of a university, including campus culture, school spirit and academic atmosphere, has a more essential and crucial connotation, and it'll directly influence the quality of talent cultivation. Academic atmosphere construction is more than a teaching and scientific research job, it is also an issue of ideology building. It will be a lifetime benefit for students to develop a good study style.

In recent years, universities and colleges have made many explorations and attempts to boost the construction of academic atmosphere and school spirit. Among them, tutor system has been widely accepted, here not only the professional mentor system that has already been implemented in universities is involved, it also includes the subject tutor system aimed at senior undergraduates and the enterprise tutor system directed at off-campus internship practice. As a new teaching reform content of higher education in a new epoch, tutor system has attracted more and more attention in terms of the relation with cultivating and building students' good academic attitude and study style.

\section{Implementation of tutor system beneficial to enhancing students' ideological and political education and moral education}

Zhu Kezhen, a famous educator, pointed out,"Professor is the soul of university, whether the study style of a university is good or not totally depends on professors." when he was president of Zhejiang University in 1936. Thus it can be seen that attaching importance to professors and tutors as well as the idea that study is as important as person-hood has been rooted in modern higher education ever since long ago. 
Ideological and political education and moral education for students is a systemic project. It's very vital for strengthening ideological and political education and moral education to build a moral system for all members. Among them, there is no doubt that teachers' setting themselves as examples will affect the students unconsciously. According to educational targets and teaching plans as well as students' characteristics, in order to do well in students' ideological and political education, make a concrete guidance in students' majors and moral education and offer suggestions on students' development directions, teachers should be required possess an intensive sense of innovation and consciousness of improving innovation ability, and constantly promote their own professional quality. If teachers improve their own quality and students' admiration for teachers are successively deepened, teaching work will be also enhanced. The "distance" between teachers and students are shortened, which does good to build a new type teacher-student relationship, then teaching and talent cultivation will be put into reality.

\section{Implementation of tutor system beneficial to motivating the student's studying enthusiasm and initiative}

On the premise of the credit system, tutors should instruct students to grasp the general situation, development trend and social demands of the major,as well as assist students to master a comprehensive and deep knowledge of their majors, which will be beneficial to motivating the student's studying enthusiasm and initiative.

Tutors should know well with their students, be aware of their basis and hobbies, accept their consultations of course selection, and propose reasonable course selection schemes and special cultivation plans based on students' specific conditions and the situation of college educational source. These are favorable to helping students to know the knowledge structure of disciplines and the overall framework of the guiding ideology on undergraduate course teaching plan based on the credit system, and helping students to master the relations between courses and relevant disciplines. From secondary school to university, for the changeable environment, students are ideologically immature and mentally unstable. Implementation of tutor system is favorable to helping the student to transit from secondary school to university smoothly. Through the two-way communication between teachers and students, the teacher will have a solid understanding of the student so as to strengthen the pertinence of teaching.

From an important aspect, implementation of tutor system in senior students enables tutors to help students build a right employment view. Tutors combine students' employment objectives with their cultivation schemes, and they are responsible to instruct and recommend students choose their jobs, which will dramatically alleviate the graduates' psychological pressure of "employment difficulty" and motivate their enthusiasm of studying.

\section{Implementation of tutor system beneficial to students to cultivate good attitude toward academic research}

In modern academic system, high degrees are granted to these academic talents possessed creativity. Implementation of tutor system requires the tutor of not only rigorous academic attitude and superb teaching art, but also constantly accumulated and innovative academic spirit. Tutors should actively carry out normal academic criticism, gradually make their academic titles of every phase deserve the merit and match the reality.

Through tutors' words and deeds, students can gradually form a rigorous, faithful and surefooted attitude. In research, getting away from blindly following others is very important in front of commercial temptation. It is beneficial for students to keep calm instead of falling into the swirl of utility, and it is favorable for students to develop good academic characters, to explore each unknown field with serious academic attitude and peace of mind, to try each way of solving problems and to know that every achievement is valuable. 


\section{Implementation of tutor system beneficial to further perfecting the management of the credit system and improving teaching quality}

As an immemorial institution, tutor system, with the development of the credit system, has arisen again in today's universities with a new style and it has been a new form of "teaching and talent cultivating". The main form of "tutor system "is the adoption of two-way selection between students and tutors. Tutors should not only have responsibility of teaching and coaching students, but also give consideration to students' life, quality and behavior.

On the condition of the credit system, students are entitled to select courses by themselves, but there are quite a large percentage of students, especially the junior students, are not sure of their own choices. Implementation of tutor system is helpful for students to freely select courses and majors on the premise of instructions. With the help of tutors, students will raise their awareness of curriculum provision and professional content and will make an overall arrangement of basic, specialized and some hot courses, which enables the student to legitimately arrange the learning process and to ensure the learning quality based on their receptivity. Similarly, implementation of tutor system is helpful for teachers to make reasonable arrangements of course content according to students' practical needs. For instance, set a proper number of theory-improving courses to improve students' theoretical quality and meet the need of the student who is determined to work on theoretical study; enrich the content of practical courses and enhance the strength and depth of practical courses to meet the cultivation need of students' innovation ability.

\section{Conclusions}

as an essential content of the credit system of higher education in new period, tutor system is given a new connotation, and it offers the student and teacher the opportunities of two-way communications, matching the principle of teaching students' in accordance with their aptitude, adapting to students' personalized development, as well as conforming to the educational idea of "an all-round person". Tutor system not only drives universities to form good academic atmosphere, but also has a promotion effect to the teacher of universities, and it enhances the teacher's responsibility of teaching and cultivating talents, requires the teacher improve their professional level from all aspects, which does good to the promotion of teaching quality of universities.

\section{Acknowledgements}

This research was financially supported by the "13th Five-Year" project planning of the Scientific and Technological Research Project of Department of Education of Jilin Province in 2016, China (Grant No. GH16071).

\section{References}

[1] Yi-ming liu. Academic discipline construction and talent cultivating college students [J], continue to education research, 2011, 12:166-168

[2] Han Yubin; Grader; Huber. Study style construction of colleges and universities question discussion [J], heilongjiang science, 2015, 11: 57-58

[3] Yu-qin zhang. Tutorial system and study style construction of colleges and universities mechanism innovation [J] ,coal of higher education, 2009, 06: 82-84

[4] Gu Qian. Effect and countermeasures of the tutorial system in colleges and universities to explore - in law school of southwest university of science and technology undergraduate tutorial system[J]. Journal of huangshan college, 2012, 02: 92-95 
[5] Qian Xiaoming; RongHuaWei; Qian Jingzhu. Education practice and thinking based on the tutorial system undergraduate students' innovative entrepreneurial training plan [J]. experimental technology and management, 2014, 07: 21-24

[6] Maike; Zhuo-ran wang; Tutorial system development in the university of Oxford [J]. heilongjiang province higher education research, exploration and revelation 09, 2012: 23 - 25

[7] Lv Yisong; Ying-ying li; ShangJianHui. Review of undergraduate tutorial system in colleges and universities at home and abroad research [J]. education teaching BBS, 08, 2013: 186-188

[8] Deng Mingyang. Double tutorial system based on the cooperation between colleges training mode exploration [J]. vocational and technical education, 20, 2013: 57-59

[9] Zhi-xia zhang; Zi-long zhang; Zhang; Pan Huiping. Exploration and construction long-term mechanism of Work-integrated learning personnel training mode of double tutorial system [J]. Fujian computer 2013, 01: 48-49 